\title{
TREND ANALYSIS OF RAW WATER PARAMETERS IN RIVER BENUE AT THE REACH OF MAKURDI, NIGERIA
}

\author{
I. M. AHO, J. T. UTSEV AND M. O. ISIKWUE
}

\begin{abstract}
This study ascertained the extent of pollution of the water body of river Benue at the reach of Makurdi. Trend analysis gives an insight to the possible outcome over a period of time in data processing. In this study, available data for twelve points ranging from $1-12 \mathrm{~m}$ distance, and some laboratory analysis were used to estimate the trend of Escherichia Coli (E.coli), Biochemical oxygen Demand (BOD) and chemical oxygen demand (COD) in river Benue at the reach of Makurdi, Benue State. The concentration of E.coli ranged from $584.7 \mathrm{cfu} / 100 \mathrm{ml}$ to $1067.1 \mathrm{cfu} / 100 \mathrm{ml}$, BOD values ranged from $727.3 \mathrm{mg} / \mathrm{l}$ to $870.4 \mathrm{mg} / \mathrm{l}$ and COD values ranged from $1454.7 \mathrm{mg} / \mathrm{l}$ to $1758.6 \mathrm{mg} / \mathrm{l}$. The values increased with distance with the highest E-coli, BOD and COD at the $12 \mathrm{~m}$ distance. Three regression models for trend projection were developed. The trend shows that, the water quality of river Benue is not pleasant. Some recommendations are made and if adopted will help to improve the quality of the water for consumption and other recreational purposes.
\end{abstract}

KEYWORDS: Trend Analysis, River Benue, Water Quality, Pollution, Raw Water

\section{INTRODUCTION}

Water is the most essential resource to both man and other living organisms. And as such the importance of water cannot be overemphasized. Historically, it has been an important factor in determining the settlements of people. Water is available in large quantity as can be seen in oceans, sea, rivers, springs, lakes, ponds. However, lack of quality precludes their uses for many purposes as a result of pollution. It is known as a universal solvent because it easily dissolves most solvent to form a solution. The unique property enables it to be used, in a wide range of important activities (Utsev and Aho, 2012).

Apart from air, water is the most important element to man. It is essential to humanity and the largest source of fresh water lies underground. It constitutes the largest part of most living matters. The human body takes from $55 \%$ to $70 \%$ water depending on body size to function properly (Jeffery, 2007).
Water is universally accepted as one of the principal element of life and may also pass the test of a limited renewable resource (Nwaogazie, 1990). Public water supply depends on the population of people living in the required area. These include homes, schools, hospitals, workplaces, commercial and some industrial activities and fire fighting. The total water demand on a municipal water supply system is the sum of all the individual demands (from toilet flushing, lawn watering, industrial cooling, and street washing) during a stated period. Demand is not constant but varies during the day, night and with season. Consequently, water demand in a particular community is normally specified in terms of average daily demand (Mand, 1991).

Over the years a considerable amount of time and efforts have been devoted to the improvement of water quality in rivers employing a combination of heuristic and material techniques. Generally, rivers are known to have multiple uses in every sector of development like agriculture, industry, transportation, public water

I. M. Aho, Department of Civil Engineering, University of Agriculture, PMB 2373, Makurdi, Nigeria.

J. T. Utsev, Department of Civil Engineering, University of Agriculture, PMB 2373, Makurdi, Nigeria.

M. O. Isikwue, Department of Agricultural Engineering, University of Agriculture, Makurdi. PMB 2373, Makurdi, Nigeria. 
supply etc. conversely they are used as sites for waste disposal. Waste from industries, domestic sewage and agricultural practices find their way into rivers resulting in large scale deterioration of the water quality. Most often, the discharge of these wastes results into levels that are of health threat to the surrounding environment and even man (Henry and Heinke, 1989).

Kumar (2011), reported that the pollution of a river could result to the spread of diseases like cholera, typhoid fever and diarrhea. Studies have shown that the consumption of highly contaminated water can cause injury to the human body. Toxins within water can harm or even kill aquatic and other animal that may have accidently or ignorantly feed on the infected organisms. The accumulation of wastes like urea, animal manure and vegetable peelings in water may lead to the growth of algae and other aquatic plants, the consequences is increase rate of microbial activities. This situation may result in depletion of dissolved oxygen causing the death of aquatic animals.

Madison (1985) reported that, the increase in anthropogenic activities as well as natural processes such as precipitation inputs, erosion, weathering of crustal materials and degradation of surface waters have rendered most water bodies unsuitable for their multipurpose usage. The growing problem of degradation and human activities on river ecosystem has made it important for continuous monitoring of water quality of rivers to evaluate their state of pollution Ayoade, 1988 and Ball, 2009). Information obtained from such a study will help in preventing some common water borne diseases.

\section{The Study Area}

Makurdi town, the study area is the headquarter of Makurdi Local Government which was created in 1970. Today, Makurdi serves a dual purpose, both as Local Government Headquarters and the State capital of Benue. Makurdi lies on both bank of River Benue; within latitudes $7^{\circ} 45^{`} \mathrm{~N}$ and longitudes $8^{\circ} 26^{`} \mathrm{E}, 8^{\circ} 36^{`} \mathrm{E}$ (Wikiedia, 2009). It is bounded in the North by Guma Local Government Area, in the East by Gwer West Local Government Area, in the South by Gwer Local Government Area and in the West by Tarkaa Local Government Area.

Makurdi metropolis, located in the River Benue valley, experiences a tropical climate with two distinct seasons; the wet and dry seasons.
The annual rainfall in Makurdi is about $150 \mathrm{~mm}$. The rainy season starts in March/April and ends in October/November, with the highest rainfall usually between July and September. Early and late rains are usually torrential with high wind, thunder storms and squalls.

Makurdi town also experiences two distinct weather situations; the harmattan with cool and chilly weather experienced from December to early February; Hot weather and high temperature experienced between early February and April (Wikiedia, 2009). The mean monthly temperature ranges between $17^{\circ} \mathrm{C}$ to $36^{\circ} \mathrm{C}$. The high temperature is attributed principally to the proximity of the river due to the reflection of solar radiation from the river.

Mineral and natural resources found within Makurdi town include glass, sand, and barifes, which are exploited locally by individuals and sold to industries outside the state. Clay is also found in the bank of the River Benue that traverses the local government area; it is also exploited locally for the production of burnt bricks whose patronage is within and outside the state (Anhwange, et al., 2012).

The Makurdi formation consists mainly of sand stones, mud rocks and subordinately of Shelly and limestone. The zone is characterized by flat to mild sloping topography, medium to high soil depth and loose soil texture. The aquifer is mainly unconfined. The study area lies in an undulating plain. The relief ranges from $100 \mathrm{~m}$ above mean sea level by flood plain of Benue River to $600 \mathrm{~m}$ around kungana hill. The main streams that drain the area are River kereke at the North Eastern part, River Bar at south western part and River Mu at the South Eastern into River Benue.

River Benue is one of the major rivers in Nigeria. It starts from Cameroonian mountains and flow westwards through Makurdi to meet the River Niger at Lokoja in Kogi State. Its tributaries include but not limited to Rivers Donga, KatsinaAla, Bantaji and Taraba. Along the Makurdi New Bridge, the river is $1.194 \mathrm{Km}$ wide with average depth and cross sectional area of $7.82 \mathrm{~m}$ and $4608.42 \mathrm{~m}^{2}$ respectively. The valley of the river which is covered with metasediments consists of land area below $300 \mathrm{~m}$ above sea level. The flood plain, which is characterized by extensive swamps, is good for dry season irrigated farming.

River Benue provides natural water and sand in commercial quantities to the environs. Benue Roof Tiles Company is a beneficiary of the natural resource. Makurdi formation is a member 
of sedimentary basin covering a large portion of Nigeria. The sand stones in Makurdi belongs to the Ezeaku shale group, which is topped by Agwu shale formation. The formation composed of three zones, being the Makurdi lower sands which can be divided into two sections found around the Makurdi airport (Wikiedia, 2009).

At the reach of Makurdi, the study area, the river is subjected to various sources of pollution. Industrial wastes from Benue Brewery Limited (BBL) and Nigeria Bottling Company (NBC) all are channeled into river. Also, wastes from markets and abattoir are washed into the river. Other sources of pollution of the river are faeces from humans defecatingdirectly in the river, animal and human wastes washed from land to the river as well as fertilizers and other chemicals applied to the crops that are usually grown at the river banks (Madison, 1985). From September $13-19^{\text {th }}$, 2012, more than 5000 people have been displaced and 800 houses submerged in Makurdi and its environs following the over flowing of the River Benue as a result of the release of excess water from Lagdo Dam in Cameroon increasing the level of pollution of the river.

Water from River Benue is needed for domestic, industrial and agricultural purposes to supplement the existing surface source in areas not covered by the current distribution network (Anhwange, et al., 2012). Considering the fact that, Makurdi is growing and River Benue is the major source of water supply for the inhabitants, incidences of water related diseases in this area has necesitated the decision to study its raw water quality parameters especially as it affects man. The study is aimed at analyzing the trend of the raw water parameters in River Benue at the reach of Makurdi and develop models for trend projections of the raw water parameters under consideration.

\section{METHODOLOGY}

\section{Water Sampling}

Grab water samples (random sampling) were collected just below the water surface at four industrial wastes discharge points into River Benue: (1) Benue Brewery Limited (BBL), (2) Nigeria Bottling Company (NBC), (3) Abattoir and (4) Market. These samples were collected in three replications. Three water samples were collected at both upstream and downstream of these discharge points. All water samples, were collected with sterilized one litre containers. These samples were preserved in an ice dust and taken to laboratory where the analysis were done within $48 \mathrm{hrs}$ after collection.

\section{Water Analysis and Parameters}

The water analyses were done in thelaboratory within 48hrs to avoid destabilization of the samples. The parameters analyzed are: Biochemical Oxygen Demand (BOD), Chemical Oxygen Demand (COD), and Escherica Coliform (E.Coli). All the analyses were done using the appropriate water sample testing meters and in accordance with the standard methods for examination of water as waste water (Apha, 1988).The trend projection was evaluated using correlation analysis.

\section{RESULTS AND DISCUSSION}

The results of E-coli, BOD and COD with their trend projections are briefly discussed below:

\section{E-coli}

The concentration of $\mathrm{E}$. coli ranges from 584.7 $\mathrm{cfu} / 100 \mathrm{ml}$ to $1067.1 \mathrm{cfu} / 100 \mathrm{ml}$ in River Benue at the reach of Makurdi from 2001-2012 with the highest value in the year 2012 (Fig. 1). This signifies the rate of pollution of the water and if taken without proper treatment, the individual is liable to contract water related diseases such as; typhoid fever, amoebic dysentery, cholera, diarrhea, hepatitis and salmonellosis (NAFDAC, 2004 and NESREA, 2009). The trend projection for $E$-coli is given by $Y_{E \text {.coli }}=42.17 X+782.34$. 


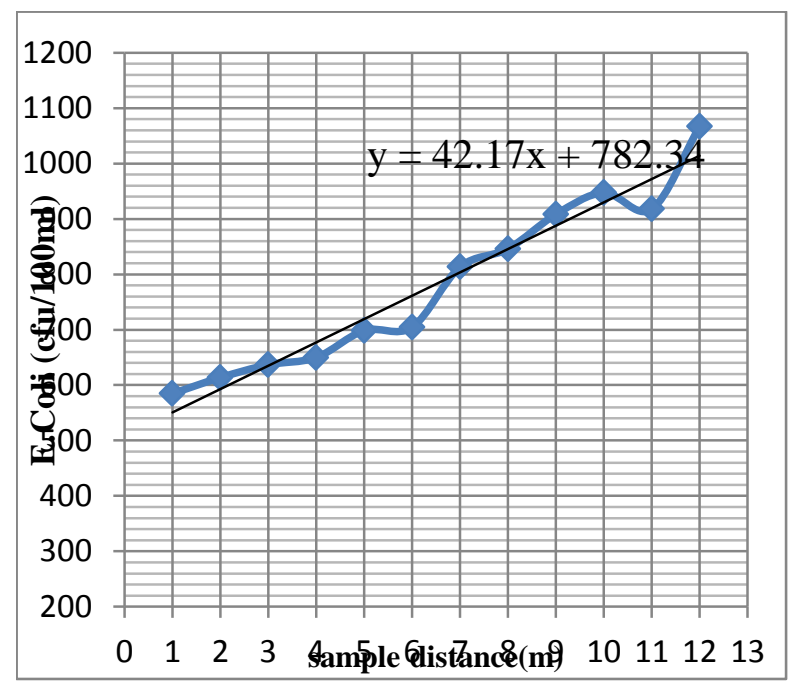

Fig. 1: Trend Analysis for E.Coli.

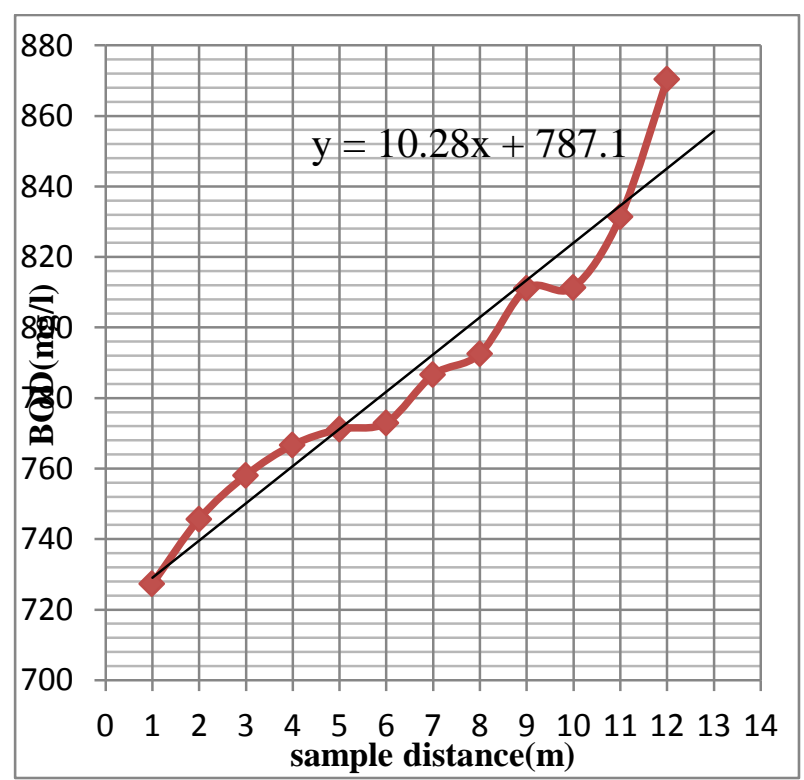

Fig. 2: Trend Analysis for BOD

Biochemical Oxygen Demand (BOD) ranges from $727.3 \mathrm{mg} / \mathrm{L}$ to $870.4 \mathrm{mg} / \mathrm{L}$ from the distance of 12 metres covered in the study. BOD values were relatively low, buthighest at the last point (Fig. 2) of $12 \mathrm{~m}$ distance. The amount of putrescible organic matter present in the water at River Benue in Makurdi was very high, thereby showing the level of pollution. High BOD values indicates polluted water. BOD value is also dependent on the dissolved oxygen in the water. When the dissolved oxygen drops below a certain level, the life forms in that water are unable to continue at a normal rate (Madison, 1985 and Michael, et al., 2003). Addition of waste to the river reduces oxygen to less than 5 $\mathrm{mg} / \mathrm{L}$, (river's aquatic minimum oxygen content which only few species of aquatic life will survive). The trend projection is shown as $\mathrm{Y}_{\mathrm{BOD}}=$ 10.28X + 787.1.

\section{COD}

Figure 3 shows concentration of chemical oxygen demand (COD) values ranging from $1454.7 \mathrm{mg} / \mathrm{L}$ to $1758.6 \mathrm{~m} \mathrm{~g} / \mathrm{L}$ for between 1 to $12 \mathrm{~m}$ distance. 
The values increase as the distance increases with the highest value at 12 metres which indicates high oxygen requirement for a sample that is susceptible to oxidation by strong chemical oxidant. The least value of COD was noticed to be at $1 \mathrm{~m}$ distance signifying low oxygen requirement for the sample of water in River Benue for oxidation by strong chemical oxidant.

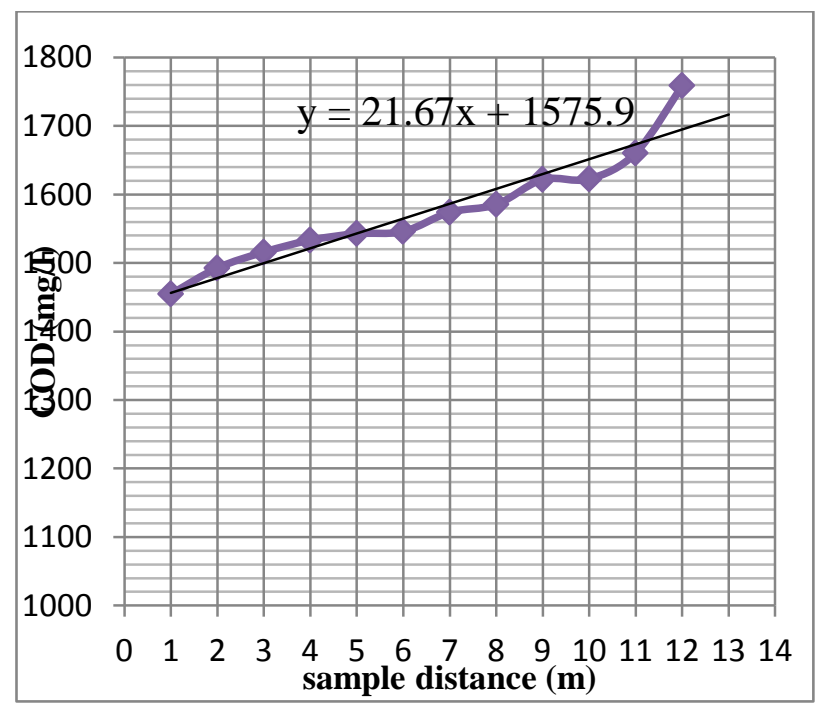

Fig. 3: Trend Analysis for COD

From Figs. $4-15$, it is observed that for $(1-4 \mathrm{~m})$ the values of COD were higher followed by BOD and then E.coli.The values of E.coli started rising from $(5-12 m)$ and reached the peak at $12 m$ above the BOD curve. This signifies the rate of pollution of the river (indication of feacal contamination). The trend projection is represented as $\mathrm{Y}_{\mathrm{COD}}=21.67 \mathrm{X}+1575.9$. 
I. M. AHO, J. T. UTSEV AND M. O. ISIKWUE
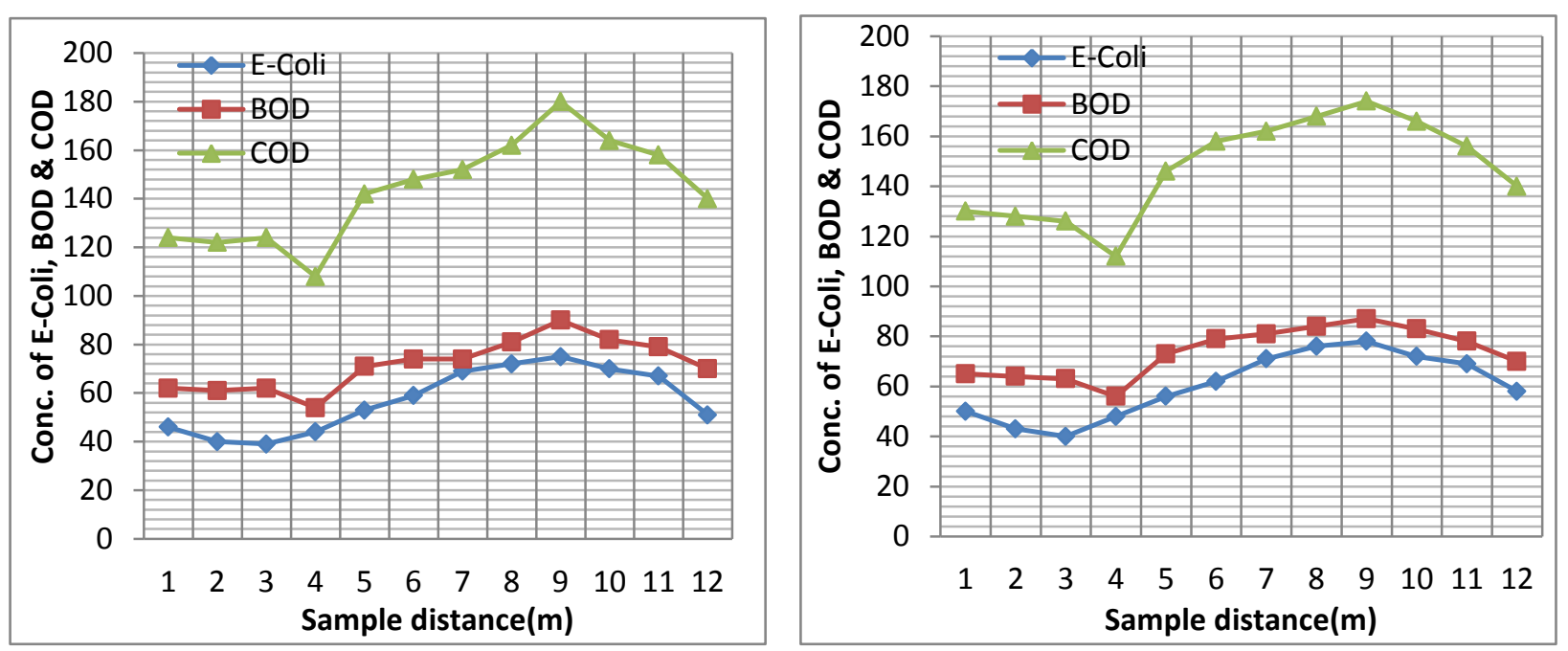

Fig. 4: Trend Analysis for E.Coli, BOD and COD For 2001

Fig. 5: Trend Analysis for E.Coli, BOD and COD For 2002
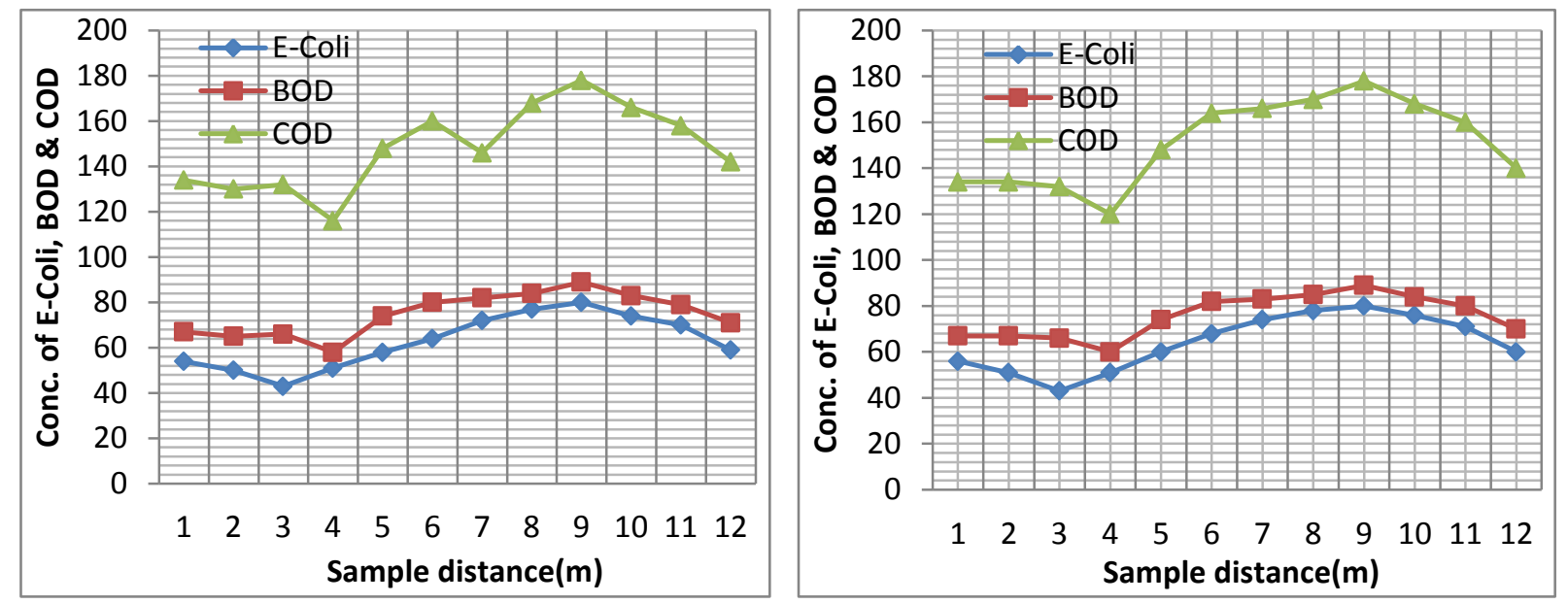

Fig. 6: Trend Analysis for E.Coli, BOD and COD For 2003

Fig. 7: Trend Analysis for E.Coli, BOD and COD For 2004
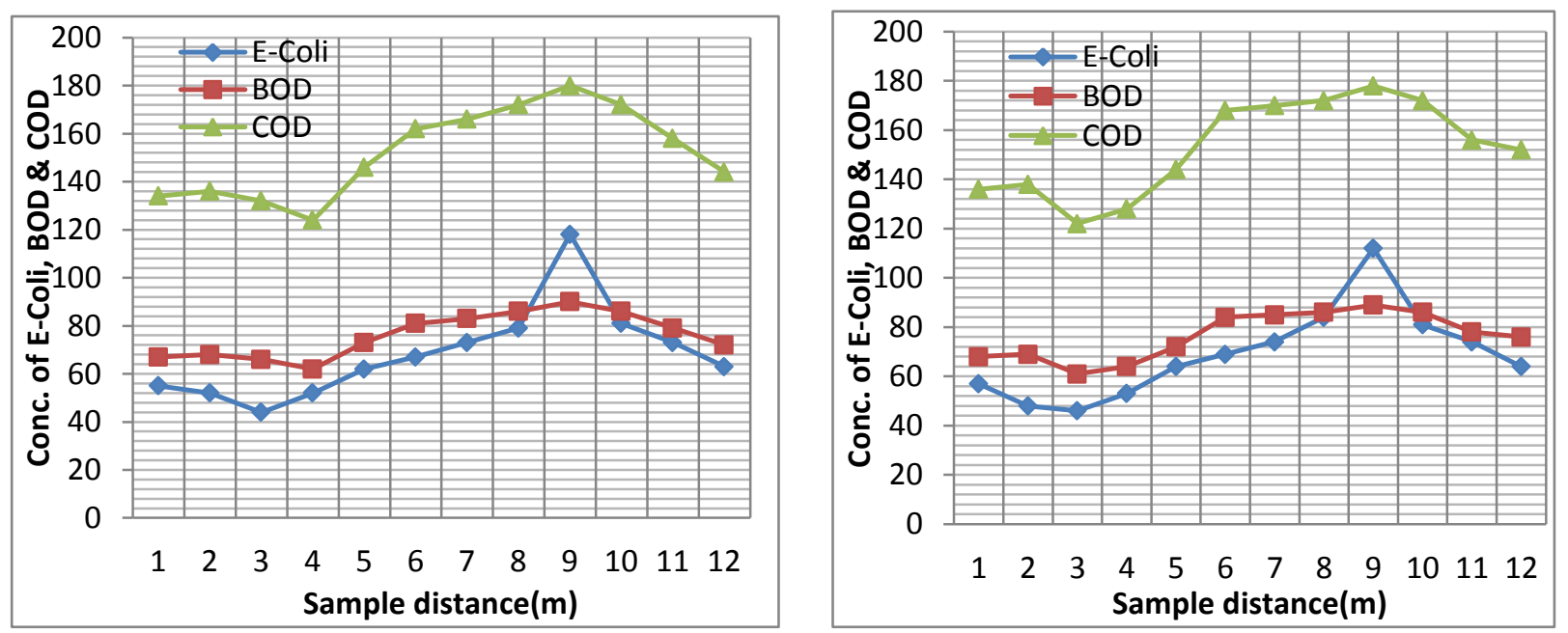

Fig. 8: Trend Analysis for E.coli, BOD and COD for 2005 

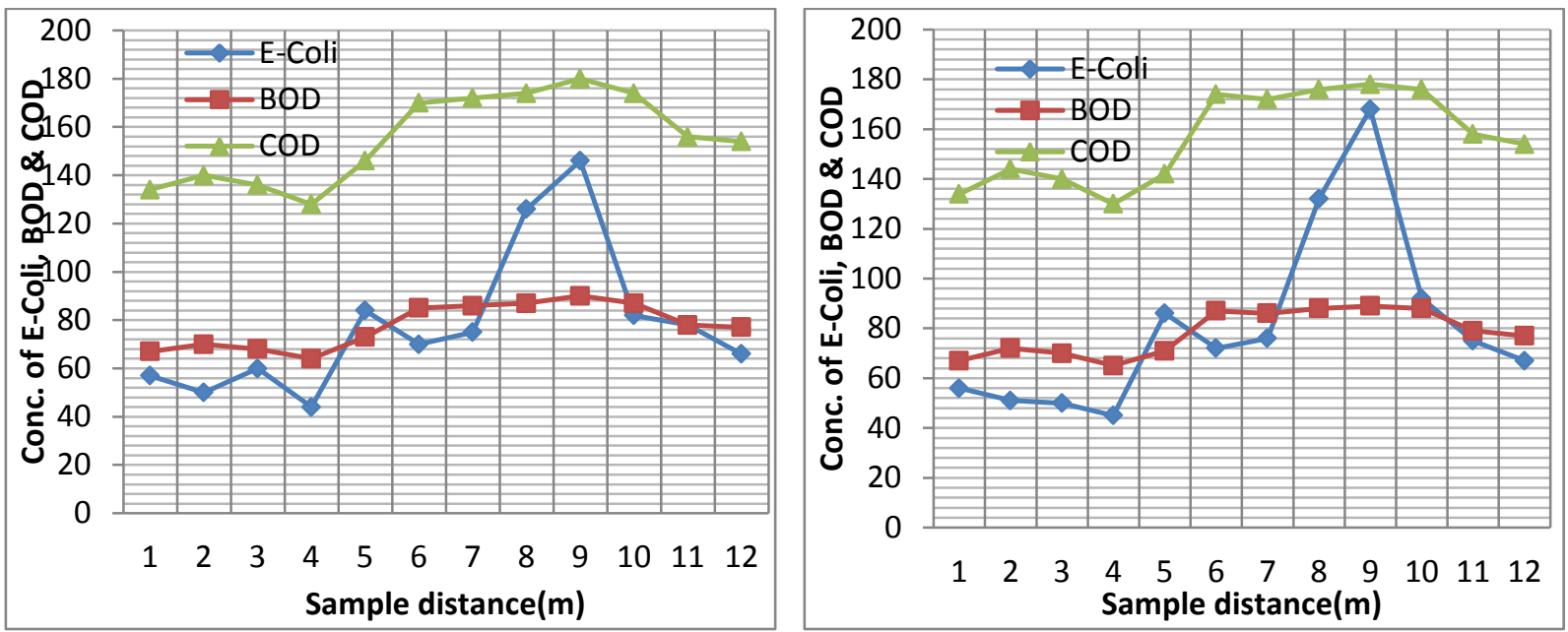

Fig. 10: Trend Analysis for E.coli, BOD and COD for 2007

Fig. 11: Trend Analysis for E.coli, BOD and COD for 2008
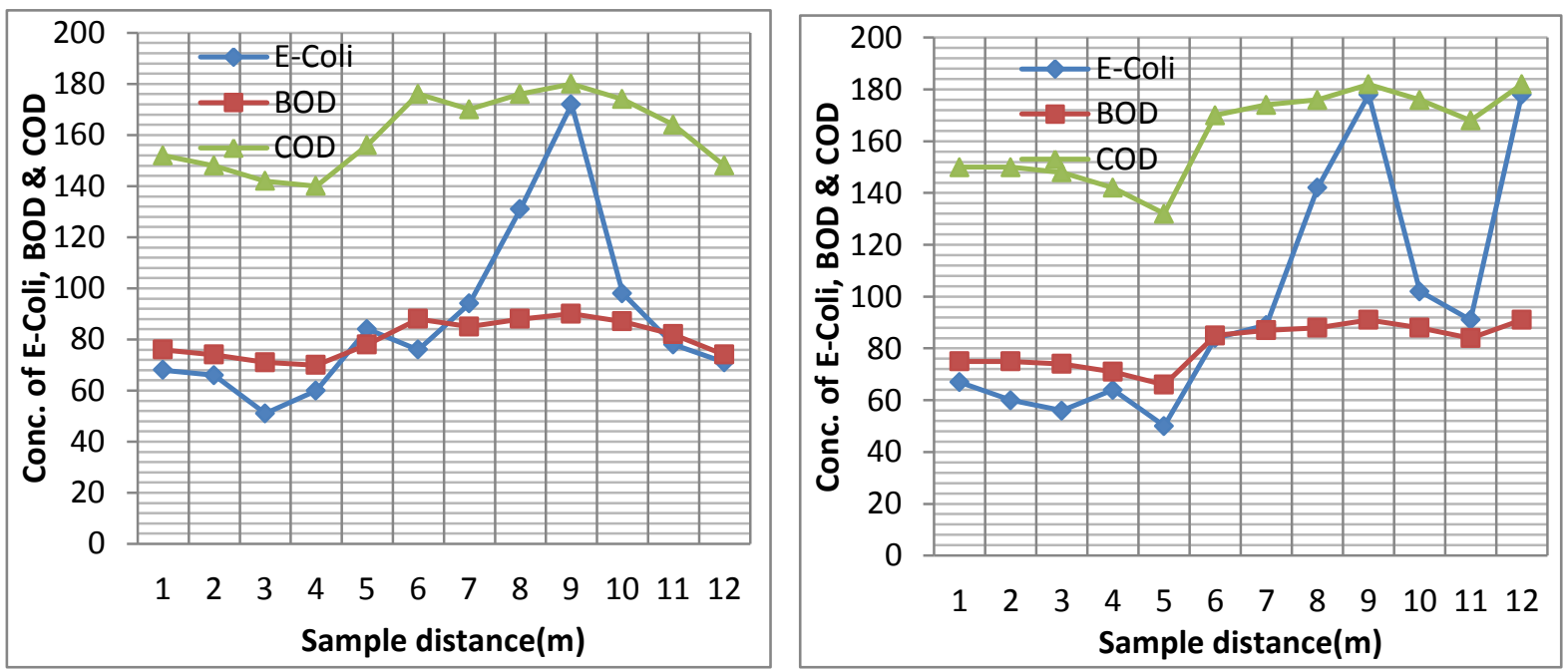

Fig. 12: Trend Analysis for E.coli, BOD and COD for 2009

Fig. 13: Trend Analysis for E.coli, BOD and COD for 2010
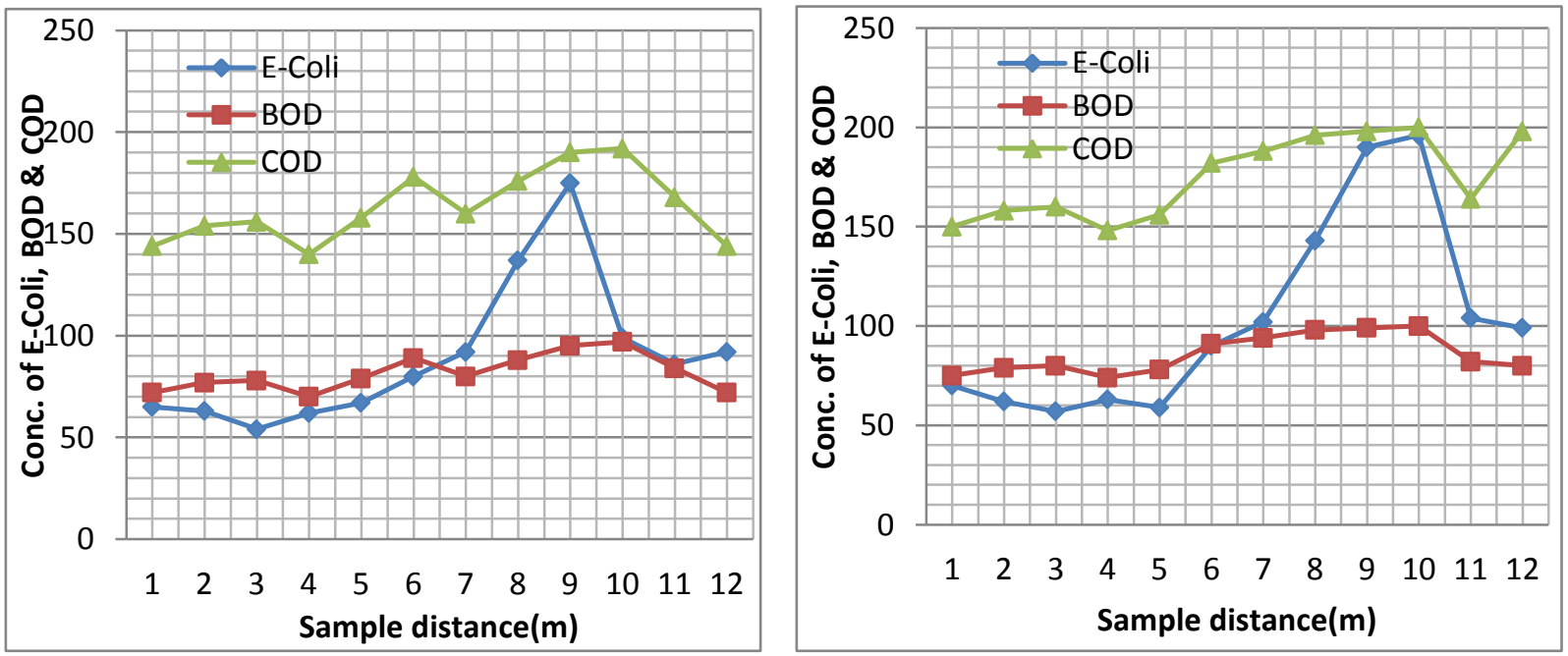

Fig. 14: Trend Analysis for E.coli, BOD and COD for 2011

Fig. 15: Trend Analysis for E.coli, BOD and COD for 2012 


\section{CONCLUSION}

Water quality information is used to protect human health, to preserve and restore healthy ecological conditions and to sustain a viable economy. The level of pollution of River Benue at the reach of Makurdi was very high. The water quality parameters which were determined include E.coli, BOD and COD. The values of COD were very high followed by BOD and lastly, E.coli. Equations for projection were developed using regression analysis approach to determine the level of water pollution (Emakwu, 2010). The results of the research revealed consistent microbial pollution which increased throughout the distance covered, as the activities within the river and around its environs remained constant. It is believed that continuous pollution of water sources by these activities may lead to some health problems both to humans and animals as it is some times experienced by the residents living along the river (Siltini, 2007, Russo, 2005, Okator, 2009 and I et al., 2002).

\section{RECOMMENDATIONS}

The observations based on the findings from available data of this research, the water quality of river Benue at the reach of Makurdi is not pleasant. Hence, the following recommendations are made:

1. Right-sizing applications of fertilizer using techniques like biodynamic farming, setting ponds can help keep polluted runoff from entering the river.

2. Waste minimization techniques should be adopted in order to minimize the waste generated from domestic and industrial sources hence, proper disposal of animal and human waste could help in reducing microbial pollution.

3. Outflow pipes that are channeled through house plumbing systems straight into the nearest rivers should be eliminated. And also, the habit of defecating in the river directly or in places that can be washed by surface runoff into the river should be discouraged.

4. Benue Brewery limited (BBL) and Nigeria bottling company (NBC) should implement FEPA (2002)guidelines by treating their wastes to meet the minimum standards before discharging into the river to minimize chemical pollution.
5. Public enlightment campaign should be intensified to educate the people on the dangers inherent in taking water from the river without any form of treatment.

6. Provision of pollution prevention and control bills at relevant quarters and enhanced monitory.

7. The Federal Government should enact water pollution control programmes which should be directed towards greatest effort towards municipal waste treatment

8. Regular water assessment should be carried out as a routine and the treatment method modified accordingly to ensure safe water at the tap.

\section{REFERENCES}

Anhwange, B. A., Agbaji, E. B and Gimba, E. C., 2012. Impact Assessment of Human on Seasonal Variation on River Benue within Makurdi Metropolis: International Journal of Science and Technology. 2, (5): 248 254.

APHA, AWWA, WPCF., 1998. Standard Methods for the Examination of Water and Wastewater, $20^{\text {th }}$ ed., American Public Health Association Washington, DC.

Ayaode, Y. O., 1988. Tropical Hydrology and Water Resources Macmillan Publishers Ltd. London. Pp.44

Ball, J and Philip, S., 2009. Microbiology for Environmental Scientists and Engineers, Macmillan Publishers Ltd. London. 87.

Emakwu, S. O., 2010. Fundamentals of Research Methods and Statistics. Selfers Academic press Ltd Makurdi. 184 192.

FEPA., 2002. Federal Environmental Protection Agency Nigeria's Federal Environmental Protection Agency.

Henry, J. G and Heinke, G. W., 1989. Environmental Science and Engineering", Prentice Hall, Englewood, Cliffs, New York. 233 
Jeffery, R., 2007. "Charting Our Water Future", Englewood Cliffs, New Jersey, USA Prentice Hall ISBN $0-13-981176-1$

Kumar J. I., 2011. An Assessment of Seasonal Variation and Water Quality Index of Sabarmati River and KharicutCannal at Ahmedabad Gujarat. Electronic journal of environment agriculture and food chemistry. 10, (8): $2772-2782$.

Madison, R. J., 1985. Overview of the Occurrences of Nitrate in Ground Water of the United States, U.S. Geology Survey Water Supply Paper. 22.75.

Mand, K., 1991. Primate Drinking Water Supply Quality, Testing and Options for Problem Waters, NRAES. 47 northeast Regional Agricultural Engineering Services Ithaca N.Y.

Michael, R. P., James, J. P and James, R. M., 2003. Biochemical oxygen demand; environmental and ecological chemistry. Vol. II,

NAFDAC., 2004. National Agency for Food, Drugs, Administration and Control.

NESREA. 2009. National Environmental Standards and Regulations Agency, 239.

Nwaogazie, I. L., 1990. Pollution Modeling, a Necessity for Provision of Water for all Nigeria, Nigerian Journal of Technology Press. 2: $49-55$.
Okafor, N., 2009. Aquatic and Waste Microbiology, Forth Dimensoin Pub. Co. Ltd., Enugu. First ed. 1 - 4.

Pi, J., Hirashi, Y., Kumagai, Y., Sun, G., Yoshida, T., Aikawa, H., Rich, C. H and Shimojo, U., 2002. Envidence for Induction of Oxidative Stress Caused by Chronic Exposure of Chinese Residents to Arsenic Contained Drinking Water, Environmental Health Perspectives. 110, (4): $331-336$.

Russo, E. 2005. "The Birth of Biotechnology". Nature. 421, (6921): $456-457$.

Siltini, T. G., 2007. The Art and Science of Chemical Analysis, John and Sons, New York. 102.

Utsev, J. T and Aho, M. I., 2012. Water Shortage and Health Problems in Benue StateNigeria: Impacts and Prospects for solutions. International J. Sci. and Tech. Research, 1, (8): 79-85.

Wikipedia., 2009. "Benue State, Nigeria", Retrieved from hpp/en.wikipedia.org/wiki/Benue-State. 